\title{
Boon Phawet: A Comparative Study of a Phu Tai, Tai-Lao and Kaleung Religious Ceremony in North-eastern Thailand
}

\author{
Banjong Lawalee ${ }^{1}$, Boonsom Yodmalee ${ }^{1} \&$ Sitthisak Champadaeng $^{1}$ \\ ${ }^{1}$ The Faculty of Cultural Science, Mahasarakham University, Khamriang Sub-District, Kantarawichai District, \\ Maha Sarakham Province, Thailand \\ Correspondence: Banjong Lawalee, The Faculty of Cultural Science, Mahasarakham University, Khamriang \\ Sub-District, Kantarawichai District, Maha Sarakham Province 44150, Thailand. E-mail: \\ blawalee140@hotmail.com
}

Received: June 9, 2014 Accepted: July 9, 2014 Online Published: September 22, 2014

doi:10.5539/ach.v7n1p24 URL: http://dx.doi.org/10.5539/ach.v7n1p24

\begin{abstract}
This is a qualitative investigation utilizing survey, observation, interview and focus group discussion as research tools. The aims of the paper are to assess the current state of the Boon Phawet ceremony, compare the customs between Phu Tai, Tai-Lao and Kaleung ethnic groups and analyse what they reveal about culture and society. The results show that the principles of Boon Phawet in all three groups are similar. The ceremony is held in the fourth month according to the traditional North-eastern social code of heet $12 \mathrm{kong} 14$. It is a religious ceremony to pay respect to Phra Malai, an arhat who descended to hell to ease suffering. The main components of the ceremony are a Phawet fabric parade, the Tet Mahachat sermon and a Kan Lon parade. There are a number of group-specific particularities, including the use of elephants in the parade of the Kaleung group. Problems with Boon Phawet revolve around a lack of active inheritance and care from the younger generations. For the continuation of Boon Phawet traditions, a conservation model must be determined that appeals to modern society.
\end{abstract}

Keywords: Boon Phawet, Isan, Phu Tai, Tai-Lao, Kaleung, inheritance

\section{Introduction}

All humans possess instinct, a sense of fear and survival that allows them to avoid danger. When humans are confronted by a threat that is beyond their power to stop, their instinct tells them to seek aid and shelter. Mental suffering is difficult threat to shelter from and in its face humans need comfort and reassurance. This psychological support comes from belief and faith, the evolution of which leads to religion, a moral code, values, law and customs that control society and nations by promoting peace and cooperation. In this way religions become important social and national institutions (Channarong, 1999).

The people of North-eastern Thailand (Isan) are predominantly Buddhist and have a set of unique traditions. The distinctive heritage of Isan is an ancient tool that has given the region and its people a collective identity. There are three general categories of ceremonial customs found in Isan: 1) Life-cycle ceremonies, 2) occasional ceremonies and 3) seasonal ceremonies. Aside from these, there are routine customs derived from traditional belief that are practiced in everyday life (Tanta-ariya, 2005).

Boon Phawet, or Boon Tet Mahachat is a ceremony with a history dating back to the era of the lifetime of the Lord Buddha and is mentioned in the legend of Phra Malai, an arhat who descended to hell to ease suffering. For Isan people, Boon Phawet is more significant that everyday merit-making (Peetawatchai, 1973). It has been inherited as part of the heet 14 kong 14 social code, which states that, at the arrival of the fourth month, people must help to collect dok jan (Butea monosperma), weave bamboo and attach dok jik (Barringtonia acutangula (L.) Garetn). In Isan, the saying goes that 'Duean sam koy jao hua koi pan kao jee, duean see koy jua noy tet matree' ' 'in the third month, you and I shall laugh and wait to mould barbecued rice. In the fourth month, the monk will give a Matree sermon']. The dok jik and matree sermon are related to the Vessantara Jataka, which is celebrated at the Boon Phawet festival annually in the fourth month of the Thai lunar calendar, which is the Thai version of the Buddhist lunisolar calendar. The ceremonies last for three days: Communal Day, Event Day and Tet Mahachat Day (Payomyong, 1976). 
Modern management of the Boon Phawet ceremony must use the original traditions as its model and include invitation of local monks, a Phawet fabric parade, the Tet Mahachat sermon and a Kan Lon parade. Boon Phawet is important to communal life in Thailand because it is a precious local identity that cannot be found anywhere else and reveals the intelligence and creativity of ancient Isan people and the inheritance of religion, legends, beliefs and lifestyle. Aside from this, the ceremonies help to conserve the values and morals of Thai people and encourage communal strength and togetherness. The beauty of the Boon Phawet lies in the promotion of social relationships, which drive the community.

The most prevalent conviction visible in the Boon Phawet ceremony is faith in Phra Upakhut and the belief that people will achieve the highest level of virtue if they listen to each of the 13 chapters of the Tet Mahachat. Phawet fabric is created and woven into finely detailed flags to decorate the ceremonial area. This subtle artwork depicts the culture of the Boon Phawet ceremony in Tai-Lao, Phu Tai and Kaleung ethnic cultures. Boon Phawet is thus an artistic and spiritual ceremony with religion at its heart (Rueangsuwan, 2003).

Boon Phawet ceremonies can still be found in almost all provinces of North-eastern Thailand. Although the size of the ceremony and its importance have diminished in some provinces, for most Tai-Lao, Phu Tai and Kaleung communities, Boon Phawet is a valuable part of the calendar year, as stipulated by the heet $12 \mathrm{kong} 14 \mathrm{code}$. The ceremony has three valuable outcomes. Firstly it generates communal cooperation and unifies society. Secondly, it gives young people a reason to return to their family home and visit their relatives. Thirdly it encourages people to make sacrifices by offering their time to help community leaders, build the community reputation and conserve local heritage (Payomyong, 1976).

Given the importance of the Boon Phawet ceremony, the research team embarked upon this investigation to assess its current state with the aim of comparing the customs between different social groups and analyzing what they reveal about culture and society.

\section{Methodology}

This is a qualitative investigation. The research combined documentary analysis and field research, which were conducted according to the stated aims. Tools for field research were survey, observation, interview and focus group discussion. Locations were purposively selected for the investigation based on the criteria that they were Tai-Lao, Phu Tai or Kaleung communities, they conserved and developed management of the Boon Phawet customs and they held an annual Boon Phawet ceremony. The communities chosen for the investigation were:

- Ban Nong Nong, I Ngong Sub-district, Chaturaphak Phiman District, Roi Et Province.

- Ban Nong Du, Thong Thani Sub-district, Thawat Buri District, Roi Et Province.

- Ban Kut Wa, Kut Wa Sub-district, Kuchinarai District, Kalasin Province.

- Ban Kokkong, Kut Wa Sub-district, Kuchinarai District, Kalasin Province.

- Ban Bua, Kut Bak Sub-District, Kut Bak District, Sakon Nakhon Province.

- Ban Kut Haed, Kut Bak Sub-District, Kut Bak District, Sakon Nakhon Province.

All results were validated using a triangulation method. The research team then analysed all collected data according to the aims of the investigation and results are here presented as a descriptive analysis.

\section{Results}

The Boon Phawet ceremony has been held in local Tai-Lao communities for as long as current residents can remember. It is an important ceremony traditionally held annually after the rice harvest season in the third or fourth month. The residents of Ban Nong Nong and Ban Nong Du currently follow the heet $12 \mathrm{kong} 14$ calendar but the Boon Phawet ceremony will be held on convenient, rather than specific days. The customs usually last for two or three days. Traditions among the Phu Tai people of Kalasin Province are very similar. In Ban Kut Wa and Ban Kokkong, the ceremony will be held annually for three years. Once the three year cycle is complete, there may be a break from holding the ceremony for one year. In Kalasin, the ceremony is organised in either the fourth or fifth month and there is the addition of Liang Pi customs, where a banquet is held for the spirits. The Kaleung people of Sakon Nakhon arrange the Boon Phawet ceremony in the fourth or fifth month annually for three years. Once the three year cycle is complete, there may be a break from holding the ceremony for one year.

The Boon Phawet ceremony of all ethnic groups has suffered due to technological innovation, the convenience of modern transport and family choice to send their children to study abroad. These three developments have caused a greater awareness and prevalence of Western culture among Thai people and led to the neglect of traditional Thai practices. Social changes such as increased consumerism have altered the Boon Phawet customs 
from their original form, although the beliefs and ceremony are still the same. The three ethnic groups hold ceremonies in the same way, with slight differences in the number of attendees and equipment used (Koonkam, 2011).

For the ceremony of the Phu Tai and Kaleung people, monks will use a generic Buddha idol to worship, while the ceremony of the Tai-Lao people specifically requires a figure of Phra Upakhut and uses a slightly different style to invite Phra Upakhut to the parade. The parades themselves are similar between ethnic groups, although the distinctive characteristic of the Kaleung parade is to incorporate elephants. The Phu Tai and Tai-Lao communities will listen to a complete 13 chapter sermon. The only difference is the use of local vocabulary and dialect, although this is minimal. The Kaleung sermon is in a 'triple-pulpit' style. The Phu Tai and Tai-Lao sermons require a community host to hold specific ceremonial dialogue with the monk during the service. For the Kaleung version, the listeners act as a communal host. Although the differences between the three ceremonies are minor, they show the adaptation of the Boon Phawet ceremony in different groups and different geographic locations. If these traditions are not followed from year to year, the people believe that spiritual sanctions will follow, such as drought or rice price inflation.

The problems with the Boon Phawet customs are similar among the Tai-Lao, Phu Tai and Kaleung ethnic groups. The equipment used to weave Phawet fabric for the ceremony is old and dilapidated. It is difficult to find people with the required expertise to make repairs. Newer versions of the traditional equipment and materials are made from plastic because the local environment no longer provides the materials required to use traditional methods. The equipment used in the ceremony changes according to occasion, belief, ceremony, social status, economic status, education and technology in the locality. The members of society adapt their versions of the ceremony to suit their surrounding environment. The Phawet fabric parade is disorganized and there is a lack of traditional knowledge inheritance to encourage the necessary continuation of Boon Phawet among young people in the community, particularly local variations. This is because the young people do not have time given their hectic working lives. The importance of the ceremony declines in the face of economic hardship because people cannot dedicate their time or money. Regarding the sermons, monks do not adapt their delivery style for new generations, causing many to ignore their teaching, particularly the young. Monks with the required expertise to give the sermon accurately and effectively may not live in the local area, which means travel is inconvenient.

\section{Discussion}

According to Wimonpan Peetawatchai (1973), Boon Phawet naturally occurred from the belief in Phra Malai. There is a potential hyperdiffusionist argument that could attribute all subsequent cultural developments, such as Boon Phawet, to a single origin in Buddhism (Elliot Smith, 1911). Indeed, this is an idea used by Pornpen Hantrakul and Atcharaporn Kamutpisamai (1984) in their analysis of Phra Sri Ariya. However, such a stance does not give adequate importance to the subtle differences in ceremony styles between the three ethnic groups. More appropriate is the Kulturkreis or culture circle phenomenon proposed by Fritz Graebner (1911) and Wilhelm Schmidt (1912-1955), which suggests that culture originates at a number of different points and spreads outwards. This better explains how three ethnic groups in three different provinces of Thailand with different dialects, histories and cultures all choose to hold their Boon Phawet ceremonies during or near the fourth month (Wannasiri, 1997). Their 'culture circles' grew and overlapped. This conclusion was also drawn by Supita Chaiysawat (1999), who examined the mutual relationship and cultural influence between the Phu Tai and Tai-Lao ethnic groups. Chaiysawat found that the Tai-Lao people have the largest representation in the Isan region and their culture has influenced the food, housing, clothing and medicine of Phu Tai people in the area. However, the Phu Tai have also made their own cultural imprint. The adaptation of both groups allows social harmony, exemplified here by the similarities and differences in Boon Phawet customs, which are perhaps more indicative of Julian Steward's cultural ecology than any diffusionist paradigm (Steward, 1955). Regardless, cultural diffusion must be acknowledged as a factor of cultural adaptation (Srisantisuk, 2001).

While studying the Boon Phawet ceremony of the Phu Tai people in Mukdahan Province, Anek Atwichai (2008) found similar components to the Phu Tai ceremonies observed in this investigation. Atwichai noted that the initial planning of the ceremony, such as date, time and place was led by local monks. In the days leading up to the ceremony, the community participated in preparation and organized the creation of Phawet fabric. This participation is a form of local education that constitutes the inheritance process. Boon Phawet has been passed on from generation to generation in this manner but is now threatened by young people choosing to leave their family home after marriage. After relocating, their ties to the local community are weaker and they are less inclined to become involved in traditional ceremonies and activities (Srisantisuk, 1989). This was a trend first noticed by Klausner (1972) during his case study of Buddhism in Ban Nong Kone and shows no sign of abating. 
The problems identified by this research were consistent with those found by Phramaha Wichien Wichiro (2010) in his analysis of Roi Et Province. Specifically, the equipment and organization of Boon Phawet in Roi Et suffered from a lack of care and active inheritance. Although the management of the ceremony has been affected by cultural change, the original beliefs remain. If management methods are identified that can relate to these younger generations, general interest in Boon Phawet may increase. Yothin Jantawee (2005) found that cultural tourism is more popular if it is effectively managed in line with modern social trends. This is not only true for tourists and can be applied as a theory for the conservation of the Boon Phawet ceremony. Jantawee's method (2005) suggests compartmentalized micro management in four categories: man, machinery, money and materials To determine whether this model is applicable to the conservation of Boon Phawet, further research is required.

\section{Conclusions and Suggestions}

Boon Phawet is a religious ceremony that can be traced back to the era of the lifetime of the Buddha and is an important ceremony for Isan people that constitutes part of the heet $12 \mathrm{kong} 14$ social code. The customs of Boon Phawet, which include creating Phawet fabric, listening to sermons and joining a local parade, all serve to strengthen community relationships and encourage participation. There are problems with the management of the Boon Phawet ceremony and the disrepair of equipment used in the creation of Phawet fabric. The biggest problem is inheritance of the ceremony because the current model of inheritance through participation is not compatible with modern society. Future research should be conducted to analyse community participation in the Boon Phawet ceremony and determine methods to modernise the management and inheritance of this valuable tradition. An additional consideration is the promotion of Boon Phawet as a cultural tourist attraction, using Phawet fabric and the history of its creation to attract interest from foreign visitors and, importantly, modern domestic society. It is this last group, the new generations of Phu Tai, Tai-Lao and Kaleung people, who will determine whether Boon Phawet develops with society or stagnates.

\section{References}

Atwichai, A. (2008). Method for restoration of Boon Phawet customs of Phu-Tai people in Mukdahan Province in order to promote local identity [in Thai]. Phd thesis. Mahasarakham University, Mahasarakham.

Chaiysawat, S. (1999). The harmonious cultural amalgamation of the Phu-Tai and Tai-Lao: A case study of Lao Yai Sub-district, Kuchinarai District, Kalasin Province [in Thai]. PhD thesis. Mahasarakham University, Mahasarakham.

Channarong, N. (1999). Culture and religion [in Thai]. Bangkok: Ramkhamhaeng University.

Graebner, F. (1911). Method of ethnology. Methode der ethnologie. Heidelberg: C. Winter

Hantrakul, P., \& Atcharaporn, K. (1984). Belief in Phra Sri Ariya and the overthrow of the virtuous in Thai society [in Thai]. Bangkok: Sangsan.

Jantawee, Y. (2005). Management of cultural tourism among hill-tribe communities: A case study of His Majesty's demonstration station project and inheritance of agriculture, forestry and the surrounding environment [in Thai]. Chiang Mai: Chiang Mai University.

Klausner, J. W. (1972). Popular Buddhism in Northeast Thailand. Rural Sociology, 55(7), 23-24.

Koonkam, A. (2011). Local customs in the social economy and community lifestyle: A case study of the Boon Phawet customs in Thailand and Laos [in Thai]. PhD Thesis. Ubon Ratchatani Rajabhat University, Ubon Ratchatani.

Payomyong, M. (1976). Analysis and comparison of Mahachat in the Central, North, North-eastern and Southern regions of Thailand [in Thai]. PhD thesis. Srinakharinwirot University, Bangkok.

Peetawatchai, W. (1973). Heet sibsong [in Thai]. Bangkok: Mahachon.

Phramaha Wichien Wichiro. (2010) A study of the successful results of listening to sermons during Boon Phawet (Tet Mahachat) in Roi Et Province [in Thai]. PhD thesis. Chulalongkorn University, Bangkok.

Rueangsuwan, J. (2003) Heet sib song kong sib see [in Thai]. Bangkok: Ubon Ratchathani University.

Schmidt, W. (1912-1955). The origin of the idea of God: A historical-critical and positive study. Der Ursprung der Gottesidee: Eine historische-kritische und positive Studie (Vol. 12). Westfalen: Aschendorf.

Smith, E. G. (1911). The ancient Egyptians and the origin of civilization. London: Harper and Brother.

Srisantisuk, S. (1989). Change to the economy, politics, society and culture in the Kuay ethnic community: A case study of Moo Ban Wan [in Thai]. Khon Kaen: Khon Kaen University. 
Srisantisuk, S. (2001). A study of society and culture: Concepts, philosophies and theories [in Thai]. Khon Kaen: Khon Kaen University.

Steward, J. (1955). Theory of culture change: The methodology of multilinear evolution. Urbana, IL: University of Illinois Press.

Tanta-ariya, S. (2005). Analysis of ancient medicinal remedies from Thai textbooks in Phang Nga Province [in Thai]. PhD Thesis. Silpakorn University, Bangkok.

Wannasiri, N. (1997). Humanity, society and culture [in Thai]. Bangkok: Kasetsart University.

\section{Copyrights}

Copyright for this article is retained by the author(s), with first publication rights granted to the journal.

This is an open-access article distributed under the terms and conditions of the Creative Commons Attribution license (http://creativecommons.org/licenses/by/3.0/). 